\title{
Hormone Receptor Positive
}

National Cancer Institute

\section{Source}

National Cancer Institute. Hormone Receptor Positive. NCI Thesaurus. Code C157055.

A finding indicating that the neoplastic cells in a breast cancer tissue sample test positive for estrogen or progesterone receptors. 